\title{
Comorbidities, medications and depressive symptoms in patients with restless legs syndrome and migraine
}

\author{
Comorbidades, medicações e sintomas depressivos em pacientes com síndrome das \\ pernas inquietas e enxaqueca
}

Karen S. Ferreira, Alan Eckeli, Fabiola Dach, José G. Speciali

\begin{abstract}
Objective: The pathophysiology of migraine and restless legs syndrome (RLS) seems to involve inherited mechanism and dysfunction of the dopaminergic system. Previous articles have shown that the frequency of RLS is higher in migraine patients than in controls. We conducted a study to evaluate comorbidities, medication used and depressive symptoms that can explain the relation between migraine and RLS. Methods: A case-control study was performed in which patients with migraine $(n=72)$ and a control group without migraine ( $n=72$ ) were interviewed. Data including RLS diagnosis, depressive symptoms, comorbidities and drugs used were evaluated. Results: There was a significant association between migraine and RLS ( $p=0.01$ ), but comorbidities such as diabetes, hypertension, anemia and drugs used did not explain this association. Depression scores, as measured by the Beck Depression Inventory, were higher in migraine patients with RLS $(p=0.04)$. Conclusion: No specific factors explaining the association between migraine and RLS were found. Symptoms of depression were more frequent in patients with migraine and RLS.
\end{abstract}

Key words: migraine, restless legs syndrome, comorbidity, medication, depression.

\section{RESUMO}

Objetivo: A fisiopatologia da enxaqueca e da síndrome das pernas inquietas (SPI) parece envolver mecanismos genéticos e disfunção do sistema dopaminérgico. Artigos anteriores mostraram que a frequência de SPI em pacientes com enxaqueca é maior do que nos controles. Desenvolvemos um estudo para avaliar comorbidades, medicamentos utilizados e sintomas depressivos em pacientes com migrânea e SPI. Métodos: Foi desenvolvido um estudo de caso-controle. Foram entrevistados pacientes com enxaqueca ( $n=72$ ) e sujeitos de um grupo controle $(n=72)$. Foram avaliados dados incluindo diagnóstico de SPI, sintomas depressivos, comorbidades e medicamentos usados. Resultados: Houve associação significativa entre enxaqueca e SPI $(p=0,01)$. Comorbidades como diabetes, hipertensão, anemia ou drogas utilizadas não explicam esta associação. Escores de depressão, medidos pelo Inventário de Beck, foram mais altos em pacientes com enxaqueca e SPI ( $p=0,04)$. Conclusão: Não foram encontrados fatores específicos que explicam a associação entre enxaqueca e SPI. Sintomas de depressão foram mais frequentes em pacientes com enxaqueca e SPI.

Palavras-Chave: enxaqueca, síndrome das pernas inquietas, comorbidade, medicamentos, depressão.

Restless legs syndrome (RLS) was first reported in 1672 by Sir Thomas Willis, a British anatomist and physician who described a patient with subjective discomfort in the legs interfering with his sleep ${ }^{1}$. In 1944, Ekbom, in Sweden, provided an accurate description of the syndrome ${ }^{2}$.

RLS is a neurological disorder characterized by disagreeable (uncomfortable) subjective feelings such as burning, itching, cramps and tingling in extremities of the legs. Patients feel compelled to move their legs (and sometimes other body parts), and the symptoms typically worsen at night. Symptoms significantly interfere with the sufferer's quality of life, both during the night (sleep disturbance) and while awake, thus impacting social activities ${ }^{3-5}$.

Diagnostic criteria for RLS were established by the International Restless Legs Syndrome Study Group (IRLSSG) ${ }^{4}$ in 2003, and according to these criteria the prevalence of RLS ranges from $2.5 \%$ to $10 \%$ with important geographic differences $^{6-8}$. The pathophysiology of RLS is poorly understood,

Department of Neuroscience, University of São Paulo, Medical School at Ribeirão Preto, São Paulo SP, Brazil;

Correspondence: Karen dos Santos Ferreira; Avenida dos Bandeirantes 3.900 / Campus Universitário Ribeirão Preto; $14048-900$ Ribeirão Preto SP - Brasil; E-mail:karenferreira@usp.br

Conflict of interest: There is no conflict of interest to declare.

Received 01 April 2012; Received in final form 31 July 2012; Accepted 07 August 2012 
but factors associated with dysfunctions of D2 dopamine receptors seem to be important. Other factors include iron deficiency, dysfunctions of the tyrosine kinase and peripheral neuronal sensitization ${ }^{5}$. The first genetic locus associated with RLS was mapped to chromosome $12 \mathrm{q}$, and five other loci have been described (13q, 14q, 9p, 2q, 20p) ${ }^{9-11}$.

Migraine is a chronic episodic disorder characterized by attacks of headache associated with nausea, photophobia and phonophobia. Over $17 \%$ of adult women and $6 \%$ of adult men suffer from migraine. Nearly $70 \%$ of migraineurs have at least one affected first-degree relative ${ }^{12,13}$.

The pathophysiology of migraine seems to involve neuronal hyper-reactivity that is often inherited ${ }^{14}$. Dopaminergic involvement in the pathophysiology of migraine is well known and is likely to be due to hypersensitivity of dopaminergic receptors involved in the onset of attacks and in the onset of premonitory symptoms (somnolence, yawning, nausea $)^{15-16}$. On the other hand, migraine attacks may often be aborted by using antidopaminergic medications, such as metoclopramide and chlorpromazine ${ }^{15-16}$.

The comorbidity between migraine and RLS was suggested before and shared dopaminergic dysfunctions may explain the association ${ }^{17-21}$. We do not know if comorbidities, medication used or depressive symptoms can explain the relation between migraine and RLS. Furthermore, only partial assessment of hidden comorbidities, such as diabetes, neuropathies or depression (often treated with medications that block dopamine) has been conducted $^{17-22}$. Nonetheless, since migraineurs are often treated with dopaminergic antagonists, which, in turn, increase the risk of RLS, it is important to consider treatment when assessing the comorbidity, and this is yet to be done. Therefore, we conducted a study to assess the prevalence of RLS in patients with migraine and to verify the possible influence of comorbidities, depressive symptoms and medication in this population.

\section{METHODS}

\section{Study design}

The study was conducted at the University Hospital of the Medical School of Ribeirão Preto, University of São Paulo. Firstly, a survey was carried out to identify employees with migraine and restless legs syndrome. Headache was assessed by self-administered questionnaires distributed to all 2,500 employees of the hospital. Out of these, 400 employees reported having no headache in the questionnaires, and 120 reported headache features that suggested migraine. Secondly, these 120 employees were individually interviewed by one of the authors (KSF), and only those fulfilling inclusion criteria were included. Controls without migraine were matched by gender, age and employment type.

\section{Inclusion and exclusion criteria}

Participants of both genders ranging from 18 to 65 years of age were included. Other inclusion criteria were migraine with or without aura according to the criteria of the International Headache Society ${ }^{23}$. We excluded patients who had more than 10 headache attacks per month in order to completely exclude those with chronic migraine from our sample. We believe that patients with chronic migraine present more abuse of medications, which could influence the dopaminergic pathways involved in the relationship between migraine and RLS.

\section{Questionnaire}

After signing the informed consent form, participants were interviewed with the aid of a questionnaire. The following information was obtained:

1. Sociodemographic data, as well as the presence of selfreported comorbidities (hypertension, diabetes, anemia);

2. Medications in current use;

3. RLS diagnosis, according to the four essential criteria recommended by the International Restless Legs Syndrome Study Group ${ }^{4}$;

4. Severity of RLS, according to the International Restless Legs Syndrome Study Group rating scale for restless legs syndrome $^{24}$.

5. Clinical characteristics and severity of migraine (visual analogue scale - VAS);

6. Self-assessment of qualitative depressive symptoms as well as severity of depressive symptoms according to the Beck Depression Inventory (BDI).

\section{Statistical analysis}

Data were entered and analyzed with the SAS version 8 by the Statistics Department of the Medical School. After exploratory analyses, qualitative variables were compared by Fisher's exact test. Significance (p) was established at the 0.05 level; Odds ratios (OR) and confidence intervals (CI) were constructed by logistic regression models. The non-parametric Wilcoxon test was used to compare quantitative data (age, duration and frequency of symptoms, as well as VAS, severity and Beck scores).

\section{Ethical considerations}

The study was approved by the Investigation Review Board (protocol 9712-2008) of our institution.

\section{RESULTS}

The sample consisted of 72 cases ( 62 women and 10 men) and 72 controls ( 57 women and 15 men). Mean age was 42.5 years for migraineurs and 40 years for controls (Table 1).

RLS was more common among those with migraine than controls (25\% versus $8 \%, \mathrm{p}=0.01$; $\mathrm{OR}=3.67$, 95\% $\mathrm{CI}=1.36-9.88)$. 
Migraineurs and controls did not differ as to other parameters (sex, age, ethnic group) (Table 1).

Migraineurs with RLS did not use more medication than controls with RLS (Table 1).

No differences in relative risk of RLS were observed as a function of presence of aura, premonitory symptoms, pain severity and frequency (Table 2).

In individuals with migraine, no differences in relative risk of RLS were observed caused by the presence of comorbidities such as hypertension, diabetes, anemia or smoking habit (Table 2). We did not detect differences between migraine patients and controls in terms of family history of RLS. (Table 1)

Depressive symptoms (qualitative ones) were more common in individuals with migraine and RLS than in those without RLS ( $p=0.03$; OR=3.98, 95\%CI 1.07-18.8). Total BDI scores were higher among those with migraine and RLS than for those with migraine without RLS ( $\mathrm{p}=0.04)$ ( Table 2).

\section{DISCUSSION}

We found a significant association between migraine and RLS in a Brazilian population, as reported in previous studies $^{17-21}$. However, most studies were case series or studies of the case-control type, a fact that weakened these results. A recent population-based and methodologically more robust study indicated that migraine is associated with RLS in a population-based cohort of women. Furthermore, as also observed in the present study, this association is not affected by migraine aura status ${ }^{21}$.

An association between migraine and RLS is plausible because it is based on clinical findings and pathophysiological considerations. From a clinical point of view, both conditions are characterized for being chronic diseases with periodic exacerbations, involving more women and having an important impact on quality of life and quality of sleep ${ }^{3,25-27}$.

Furthermore, premonitory manifestations of migraine associated with dopamine, such as yawning, nausea, somnolence and food craving, are more frequent among migraneurs with RLS than among subjects suffering from migraine alone $^{22}$. From a pathophysiological point of view, evidence suggests that these conditions may involve dysfunction of the A11 hypothalamic dopaminergic nucleus. By binding to D2 receptors, the A11 nucleus inhibits the activation of the trigeminocervical complex, which is a key region for pain transmission in migraine, from the head and orofacial structures

Table 1. Demographic and clinical data of the migraine patients and control subjects.

\begin{tabular}{|c|c|c|c|c|}
\hline & $\begin{array}{c}\text { Migraine } \\
\mathrm{n}=72\end{array}$ & $\begin{array}{c}\text { Controls } \\
n=72\end{array}$ & $\mathrm{p}$-value & OR $(95 \% \mathrm{Cl})$ \\
\hline RLS prevalence (\%) & 25 & 8 & 0.01 & $3.67(1.36-9.88)$ \\
\hline \multicolumn{5}{|l|}{ Sex } \\
\hline Female (\%) & 86 & 79 & 0.59 & $2.04(0.34-12.36)$ \\
\hline Male (\%) & 14 & 21 & 0.99 & $0.72(0.14-3.74)$ \\
\hline Age (mean) & 42.5 & 40 & 0.40 & - \\
\hline Ethnic group (white \%) & 89 & 89 & 0.99 & $1.00(0.18-5.46)$ \\
\hline RLS severity scale (mean) & 18 & 15 & 0.20 & - \\
\hline Family history of RLS (\%) & 17 & 4 & 0.99 & $1.43(0.13-16.02)$ \\
\hline Anemia (\%) & 16.6 & 20.8 & 0.59 & $2.01(0.16-15.92)$ \\
\hline Smokers (\%) & 16.6 & 9.7 & 0.47 & $1.97(0.04-22.81)$ \\
\hline Hypertension (\%) & 16.6 & 12.5 & 0.56 & $1.44(0.03-15.62)$ \\
\hline Diabetes (\%) & 5.5 & 4.1 & 0.23 & $6.09(0.09-137.6)$ \\
\hline Medication*(\%) & 16.6 & 4.1 & 0.66 & - \\
\hline
\end{tabular}

RLS: restless leg syndrome; OR: odds ratio; Cl: confidence interval. *Medication in current use.

Table 2. Clinical data of the migraine patients with or without RLS.

\begin{tabular}{lcccc} 
Migraineurs & $(-)$ RLS & (+) RLS & p-value & OR (95\%Cl) \\
\hline Aura (\%) & 29.6 & $n=18$ & 0.26 & $1.88(0.54-6.48)$ \\
Migraine attack (means)* & 5 & 44.4 & 0.45 & - \\
Intensity (means)** & 8 & 4 & 0.11 & - \\
Premonitory symptoms (\%) & 61.1 & 72.2 & 0.57 & $1.64(0.68-6.77)$ \\
Anemia (\%) & 14.8 & 22.2 & 0.48 & $1.63(0.31-7.28)$ \\
Smokers (\%) & 11.1 & 33.3 & 0.06 & $3.90(0.88-17.99)$ \\
Hypertension (\%) & 18.5 & 11.1 & 0.72 & $0.55(0.05-3.04)$ \\
Diabetes (\%) & 5.5 & 5.5 & 0.99 & $1.00(0.02-13.44)$ \\
Depressive symptoms (\%) & 46.2 & 77.7 & 0.03 & $3.98(1.07-18.79)$ \\
BDI score (median) & 5 & 7.5 & 0.04 & - \\
\hline
\end{tabular}

RLS: restless leg syndrome; BDI: Beck Depression Inventory; OR: odds ratio; Cl: confidence interval. *Days per month; **(VAS) visual analogue scale. 
to the hypothalamus and brain ${ }^{15,16}$. In addition, the $\mathrm{A} 11 \mathrm{nu}-$ cleus also sends direct inhibitory projections to sympathetic preganglionic neurons and to the dorsal horn, as well as the anterior horn in the spinal cord, which innervates skeletal muscles and are believed to be involved in sensory suppression $^{5}$; hence, dopaminergic dysfunction in this area might contribute with the sensory symptoms of RLS. Therefore, a shared dopaminergic dysfunction in the A11 nucleus may be the neuroanatomical substrate linking migraine and RLS. Also, it is known that there is an important association of RLS with changes in iron metabolism ${ }^{11}$, and, similarly, iron deposits have been observed in the periaqueductal gray matter of migraneurs ${ }^{28}$.

Another aspect that may be responsible for the association of migraine and RLS is sleep. Since sleep deprivation is an important factor triggering migraine $e^{25,26}$ and RLS causes a reduction of the quality and quantity of sleep ${ }^{27}$, theoretically, it would not be a surprise to consider that RLS may cause a worsening of the symptoms related to migraine, and that this mechanism may justify, at least in part, this association.

Patients with migraine alone or RLS only have a greater chance of developing depression ${ }^{29-31}$. In the present study we assessed depressive symptoms. BDI scores were higher in migraineurs with RLS than among those without RLS ( $p=0.04)$. Similarly, $77.7 \%$ of those with migraine and RLS self-reported having depressive symptoms compared to $53.7 \%$ of those with migraine, but not RLS ( $\mathrm{p}=0.03$ ). Therefore, depressive symptoms seem to be more frequent in patients with both migraine and RLS. However, the true role of depressive symptoms in the association between them needs to be further determined.

We found no association between demographic variables (gender, age, marital status and years of education) and headache or RLS status, as reported by others ${ }^{17-25}$.
Regarding the characteristics of migraine, in our study no association was seen between the presence of aura, premonitory symptoms, frequency and severity of pain and RLS, as suggested by previous studies ${ }^{17,20,21}$. Similarly, no differences were observed between clinical features of RLS and migraine status. Variables such as RLS severity were not influenced by migraine status in this study.

We excluded patients with chronic migraine from our sample because they use more medication, which could influence dopaminergic pathways involved in the relationship between migraine and RLS, with consequent potential bias of the results.

Finally, in this study other medical comorbidities, life style and medication used did not increase the risk of the association RLS/migraine. Some of these comorbidities have been demonstrated in previous studies ${ }^{17-21}$. Nonetheless, for some (e.g., anemia), we relied on self-report and did not perform a hematological test, which was a limitation of our study. We suggest that the low prevalence of these comorbidities limited our power to detect association, another limitation of our study.

In conclusion, the prevalence of RLS is higher in migraineurs than in controls, but specific factors to explain the association were not found. On the other hand, clinical features of migraine in patients with RLS do not differ from those of subjects without RLS, and the severity of RLS does not vary as a function of migraine status. Migraineurs with RLS have higher BDI scores when compared to all other groups.

\section{ACKNOWLEDGEMENTS}

The authors thank Dr Marcelo E. Bigal for critically reviewing this manuscript.

\section{References}

1. Willis T. The London Practice of Physics (first edition). London: Thomas Bassett and William Crooke; 1685:404.

2. Ekbom KA. Asthenia crurum paraesthetica ('Irritable Legs'). A new syndrome consisting of weakness, sensation of cold and nocturnal paraesthesia in the legs, responding to a certain extent to treatment with Priscol and Doryl -- A note on paresthesia in general. Acta Med Scand 1944;118:197-209.

3. Allen RP, Walters AS, Montplaisir J, et al. Restless legs syndrome prevalence and impact: REST general population study. Arch Intern Med 2005;165:1286-1292.

4. Allen RP, Pichietti D, Hening WA, et al. Restless legs syndrome: diagnostic criteria, special considerations, and epidemiology. A report from the restless legs syndrome diagnosis and epidemiology workshop at the National Institutes of Health. Sleep Med 2003;4: 101-119.

5. Trenkwalder C, Paulus W, Walters AS. The restless legs syndrome. Lancet Neurol 2005;4:465-475.

6. Innes KE, Selfe TK, Agarwal P. Prevalence of restless legs syndrome in North American and Western European populations: a systematic review. Sleep Med 2011;12:623-634.
7. Tan EK, Seah A, See SJ, Lim E, Wong MC, Koh KK. Restless legs syndrome in an Asian population: a study in Singapore. Mov Disord 2001;16:577-579.

8. Eckeli AL, Gitaí LG, Dach F, et al. Prevalence of restless legs syndrome in the rural town of Cassia dos Coqueiros in Brazil. Sleep Med 2011;12:762-767.

9. Desautels A, Turecki G, Montplaisir J, et al. Restless legs syndrome: confirmation of linkage to chromosome 12q, genetic heterogeneity, and evidence of complexity. Arch Neurol 2005;62:591-596.

10. Balaban H, Bayrakli F, Kartal U, Pinarbasi E, Topaktas S, Kars HZ. A novel locus for restless legs syndrome on chromosome 13q. Eur Neurol 2012;68:111-116.

11. ConnorJR, Boyer PJ, Menzies SL, et al. Neuropathological examination suggests impaired brain iron acquisition in restless legs syndrome. Neurology 2003;61:304-309.

12. Rasmussen BK. Epidemiology of headache. Cephalalgia 2001;21: 774-777

13. Becker WJ, Gladstone JP, Aubé M. Migraine prevalence, diagnosis, and disability. Can J Neurol Sci 2007;34:S3-9. 
14. Goadsby PJ, Lipton RB, Ferrari MD. Migraine-current understanding and treatment. N Engl J Med 2002;346:257-270.

15. Bergerot A, Storer RJ and Goadsby PJ. Dopamine inhibits trigeminovascular transmission in the rat. Ann Neurol 2007;61: 251-262.

16. Akerman S, Goadsby PJ. Dopamine and migraine: biology and clinical implications. Cephalalgia 2007;27:1308-1314.

17. Rhode AM, Hösing VG, Happe S, Biehl K, Young P, Evers S. Comorbidity of migraine and restless legs syndrome--a case-control study. Cephalalgia 2007;27:1255-1260.

18. Sabayan B, Bagheri M, Borhani Haghighi A. Possible joint origin of restless leg syndrome (RLS) and migraine. Med Hypotheses 2007;69:64-66.

19. d'Onofrio F, Bussone G, Cologno D, et al. Restless legs syndrome and primary headaches: a clinical study. Neurol Sci 2008;29:S169-172.

20. Chen PK, Fuh JL, Chen SP, Wang SJ. Association between restless legs syndrome and migraine. J Neurol Neurosurg Psychiatry 2010;81: 524-528.

21. Schürks M, Winter AC, Berger K, Buring JE, Kurth T. Migraine and restless legs syndrome in women. Cephalalgia 2012;32:382-389.

22. Cologno D, Cicarelli G, Petretta V, d'Onofrio F, Bussone G. High prevalence of Dopaminergic Premonitory Symptoms in migraine patients with Restless Legs Syndrome: a pathogenetic link? Neurol Sci 2008;29(Suppl 1):S166-168.

23. Headache Classification Subcommittee of the International Headache Society. The International Classification of Headache Disorders: 2nd edition. Cephalalgia 2004;24(Suppl 1):9-160.
24. Masuko AH, Carvalho LB, Machado MA, Morais JF, Prado LB, Prado GF. Translation and validation into the Brazilian Portuguese of the restless legs syndrome rating scale of the International Restless Legs Syndrome Study Group. Arq Neuropsiquiatr 2008;66: 832-836.

25. Seidel S, Hartl T, Weber M, et al. Quality of sleep, fatigue and daytime sleepiness in migraine - a controlled study. Cephalalgia 2009;29: 662-669.

26. Lipton RB, Liberman JN, Kolodner KB, Bigal ME, Dowson A, Stewart WF. Migraine headache disability and health-related quality-of-life: a population-based case-control study from England. Cephalalgia 2003;23:441-450

27. Hening W, Walters AS, Allen RP, Montplaisir J, Myers A, Ferini-Stramb L. Impact, diagnosis and treatment of restless legs syndrome (RLS) in a primary care population: the REST (RLS epidemiology, symptoms, and treatment) primary care study. Sleep Med 2004;5:237-246.

28. Kruit MC, Launer LJ, Overbosch J, van Buchem MA, Ferrari MD. Iron accumulation in deep brain nuclei in migraine: a populationbased magnetic resonance imaging study. Cephalalgia 2009;29: 351-359.

29. Yadav RK, Kalita J, Misra UK. A study of triggers of migraine in India. Pain Med 2010;11:44-47.

30. Li Y, Mirzaei F, O'Reilly EJ, et al. Prospective study of restless legs syndrome and risk of depression in women. Am J Epidemiol 2012;176:279-288.

31. Modgill G, Jette N, Wang JL, Becker WJ, Patten SB. A population-based longitudinal community study of major depression and migraine. Headache 2012;52:422-432. 